\title{
Stability, fatty acid composition and sensory properties of the M. Longissimus muscle from beef steers grazing either chicory/ryegrass or ryegrass
}

\author{
C. L. Marley ${ }^{1 \dagger}$, R. Fychan ${ }^{1}$, J. W. Davies ${ }^{1}$, V. J. Theobald ${ }^{1}$, N. D. Scollan ${ }^{1}$, R. I. Richardson ${ }^{2}$ \\ and R. Sanderson ${ }^{1}$ \\ ${ }^{1}$ Animal and Aquatic Sciences, Institute of Biological, Environmental and Rural Sciences (IBERS), Aberystwyth University, Gogerddan, Ceredigion, SY23 3EE, UK; \\ ${ }^{2}$ Food Science and Food Safety Group, Division of Farm Animal Science (DFAS), University of Bristol, Langford, Bristol, BS40 5DU, UK
}

\begin{abstract}
Research has shown both production and health benefits for the use of chicory (Cichorium intybus) within ruminant diets. Despite this, little was known about the effects of this forage, containing differing fatty acid profiles and secondary plant compounds compared with ryegrass, on beef stability, fatty acid composition or sensory properties. An experiment was conducted to investigate whether the inclusion of chicory in the diet of grazing beef steers would alter these three properties in the M. Longissimus muscle when compared with beef steers grazing perennial ryegrass (Lolium perenne). Triplicate 2 ha plots were established with a chicory (cv. Puna II)/perennial ryegrass mix or a perennial ryegrass control. A core group of 36 Belgian Blue - cross steers were used within a 2-year beef finishing experiment $\left(\mathrm{n}=6 /\right.$ replicate plot). In the $2^{\text {nd }}$ grazing year, steers were slaughtered as they reached a target fat class of 3. Muscle pH was checked 2 and $48 \mathrm{~h}$ post-slaughter. A section of the hindloin joint containing the $\mathrm{M}$. Longissimus lumborum muscle was removed and a $20 \mathrm{~mm}$-thick steak was cut and muscle samples were taken for analysis of vitamin $E$ and fatty acid analysis. The remaining section of the loin was vacuum packed in modified atmosphere packs and subjected to simulated retail display. A section of the conditioned loin was used for sensory analysis. Data on $\mathrm{pH}$, vitamin $\mathrm{E}$ concentration and colour stability in a simulated retail display showed there were no effects of including chicory in the diet of grazing beef steers on meat stability. There were also no differences found in the fatty acid composition or the overall eating quality of the steaks from the two treatments. In conclusion, there were no substantive effects of including chicory in the swards of grazing beef cattle on meat stability, fatty acid composition or sensory properties of the M. Longissimus muscle when compared with beef steers grazing ryegrass-only swards.
\end{abstract}

Keywords: cattle, Cichorium intybus, meat, lipid, forage

\section{Implications}

The use of chicory within ruminant systems is increasing due to the benefits shown for this forage in sheep production systems. However, there has been little research on the effects of using chicory in beef systems. Here, the effects of chicory inclusion in the diet of grazing steers on meat quality and sensory properties were investigated. Findings showed there were no substantive effects of including chicory in the swards of grazing beef cattle on meat stability, fatty acid composition or sensory properties of the $M$. Longissimus muscle when compared with beef steers grazing ryegrassonly swards.

\footnotetext{
${ }^{\dagger}$ E-mail: christina.marley@aber.ac.uk
}

\section{Introduction}

Chicory (Cichorium intybus) has been regarded for many years worldwide as a valuable constituent of pastures for grazing livestock. As the 1980s onwards, with the development of commercial forage cultivars (Rumball et al., 2003), the use of chicory has been steadily increasing albeit predominately in sheep and deer production systems. Research findings have confirmed the attributes for this forage include its ability to increase the productivity of finishing lambs and reduce internal helminth parasites (Marley et al., 2003). The livestock production attributes from chicory are mostly due to its high CP and energy values as well as it being highly productive agronomically resulting in an improvement in the seasonal availability of high quality forage ( $\mathrm{Li}$ and Kemp, 2005). 
Chicory leaves contains a range of secondary plant compounds, including sesquiterpene lactones (bitter compounds), tannins and other phenolic compounds (Kisiel and Zielińska, 2001). These dietary plant secondary metabolites have been shown in numerous studies to affect meat quality (Priolo et al., 2001). Most notably, degradation products of sesquiterpene lactones found in chicory, namely dihydrolactucin, tetrahydrolactucin and hydroxypenyacetic acid, were identified as the taint compounds in the milk of dairy cows on high chicory diets (Visser, 1992), leading to speculation that the same compounds could result in meat with a bitter taste compared with meat from grass-based systems. In a recent study, consumers preferred steaks from steers finished on pearl millet (Pennisetum glacum), cowpea (Vigna unguiculata) or lucerne (Medicago sativa) when compared with steaks from steers grazing chicory or bermudagrass (Cynodon dactylon) (Schmidt et al., 2013).

Consumers are increasingly aware of the importance of diet on their health and this has resulted in consumer interest in the nutritional value of foods (Scollan et al., 2006). In relation to the healthiness of meat, the industry is largely concerned with the total amount of fat and its fatty acid composition, aiming to produce meat with a higher ratio of polyunsaturated fatty acids (PUFA) to saturated fatty acids and the optimal ratio of $n-6$ and n-3 PUFA (Wood et al., 2004). Fatty acid profiles have been shown to differ among forages, with chicory reported as having a different profile and a higher total concentration of PUFA (C18:3n-3) than other forages including ryegrass (Clapham et al., 2005). In the experiment by Schmidt et al. (2013), chicory increased the ratio of $n-6 / n-3$ PUFA in the meat of grazing steers when compared with steers grazing bermudagrass, cowpea or lucerne, suggesting that including chicory in the diet of grazing ruminants would alter the total fatty acid concentration and composition of their meat.

Despite the production benefits highlighted for chicory within ruminant diets and research suggesting that the fatty acids and other secondary compounds present in this forage may alter meat properties when consumed by farmed animals, there have been no studies into the effects of this forage when compared with perennial ryegrass swards on beef quality within a temperate pasture-based beef finishing system. The aim of the experiment described here was to determine the effects of chicory/perennial ryegrass swards compared with perennial ryegrass swards on the meat stability, fatty acid composition and sensory properties of the $M$. Longissimus muscle of grazing beef steers grazing ryegrass.

\section{Material and methods}

\section{Experimental site, animals and forage treatments}

Full details of the grazing experiment, including plot establishment, grazing management and performance data are presented in Marley et al. (2014). In brief, triplicate 2 ha field plots were established with either a chicory (cv. Puna II)/perennial ryegrass (cv. Premium) mix or a perennial ryegrass control (cv. Premium) at Penglais farm,
Aberystwyth University $\left(52^{\circ} 25^{\prime} 46^{\prime} \mathrm{N} 4^{\circ} 4^{\prime} 13^{\prime} \mathrm{W}\right)$. The experiment was conducted over 2 consecutive grazing years (2010-11), with individual animals remaining on the same replicate forage plot in both years. A core group of 36 Belgian Blue - dairy cross steers (mean \pm SEM live weight: $184 \pm 4.7 \mathrm{~kg}$ aged $\sim 7$ months on Day 0 ) were retained for the whole 2-year production and finishing period, resulting in six animals per replicate plot. The measurement period ran from 25 May until 28 September and 12 April until 11 October, in the $1^{\text {st }}$ and $2^{\text {nd }}$ grazing year. In the winter period between grazing seasons, animals were housed as one group and offered a standard diet of ryegrass silage plus straw. In the $2^{\text {nd }}$ grazing year, steers were selected for slaughter as they were deemed to have reached a fat class of 3 , according the EU regulations EUROP classification (where 1 is very lean and 5 is very fat) (MLCSL, 2016). At this stage, steers from each treatment group were transported on the day before slaughter from the Institute of Biological, Environmental and Rural Sciences at Aberystwyth University to the Food Science and Food Safety Group at the University of Bristol, Langford, UK. All animal procedures followed strict guidelines as set forward in the Animals (Scientific Procedures) Act (1986) and approved by the Home Office (HO), UK and were performed under a $\mathrm{HO}$ licence. Animals were certified as not suffering any adverse effects as a result of any procedures at the end of the experimental period by the named $\mathrm{HO}$ veterinary officer.

\section{Sample collection}

Animals were housed overnight before slaughter. Animals were stunned with a captive bolt gun and killed by severing the carotid arteries. Carcasses were subjected to electrical stimulation using a low voltage electrical stimulation unit (MIRINZ, Hamilton, New Zealand) delivering $90 \mathrm{v}$ (125 to $500 \mathrm{~mA}$, pulse width 5 to $10 \mathrm{~ms}$, pulse period 57 to $80 \mathrm{~ms}$ $(14.3 \mathrm{~Hz}))$ for $60 \mathrm{~s}, 30 \mathrm{~s}$ after bleeding began. After dressing, half carcass sides were hung in a $2^{\circ} \mathrm{C}$ chiller for $48 \mathrm{~h}$ and then then quartered between the junction of the $10^{\text {th }}$ and $11^{\text {th }}$ rib. A $250 \mathrm{~mm}$-long section of the hindloin joint containing the $M$. Longissimus lumborum muscle was removed from the left side of the carcass, posterior to the $10^{\text {th }}$ rib. A $20 \mathrm{~mm}$-thick steak was cut and the muscle dissected free of subcutaneous adipose tissue. The muscle sample was vacuum packed and frozen at $-20^{\circ} \mathrm{C}$ for subsequent analysis of vitamin $\mathrm{E}$, a further steak being retained for fatty acid analysis. The remaining section of the loin was vacuum packed and conditioned at $1{ }^{\circ} \mathrm{C}$ to 14 days from slaughter. After this, three $20 \mathrm{~mm}$-thick steaks were cut and packed individually in modified atmosphere (MA) packs $\left(\mathrm{O}_{2}: \mathrm{CO}_{2} ; 75: 25\right)$ and subjected to simulated retail display $\left(4^{\circ} \mathrm{C}, 700\right.$ lux for $16 \mathrm{~h}$ out of $24 \mathrm{~h}$ ). The remaining section of the conditioned loin was frozen and stored at $-20^{\circ} \mathrm{C}$ before sensory analysis.

\section{Meat and fat measurements}

Muscle $\mathrm{pH}$ was checked at 2 and $48 \mathrm{~h}$ post-slaughter in the $M$. Longissimus between the $10^{\text {th }}$ and $11^{\text {th }}$ rib, using a Testo $230 \mathrm{pH}$ direct probe (Testo, Wilmington, NC, USA), calibrated with $\mathrm{pH} 4.0$ and 7.0 buffers. Fat colour $\left(L^{*} a^{*} b^{*}\right)$ was 
determined on the cold carcass at $48 \mathrm{~h}$ post-slaughter on the subcutaneous fat over the $10^{\text {th }}$ rib, $10 \mathrm{~cm}$ from the mid-line avoiding any blood streaked areas using a Minolta CR400 Chromometer (Minolta UK Ltd, Milton Keynes, UK) standardised as specified by Cassens et al. (1995) on a white tile. The $L^{*} a^{*} b^{*}$ system of the Commission International de L'Eclairage (Commission Internationale de l'Eclairage, 1978) was used and values for hue $\left(\tan -1 b^{*} / a^{*}\right)$ and saturation (square root of $\left(a^{*} 2+b^{*} 2\right)$ calculated. Meat colour was measured daily on two MA packed steaks on three areas of the surface of the steaks through the film lid and averaged, until the colour changed from red to brown. Two further MA packed steak was taken at day 10 , trimmed of excess visible fat around the edges, homogenised and subsampled, for analysis of lipid oxidation as thiobarbituric acid reacting substances (TBARS) by the method of Tarladgis et al. (1960) modified by the use of a Buchi 321 distillation unit (BUCHI Corporation, New Castle, DE, USA). Vitamin $E$ was analysed by the method of Liu et al. (1996), using 5,7-dimethyl-tocol as internal standard.

\section{Fatty acid composition and profile}

Fatty acids analysis was carried out by direct saponification as described in detail by Teye et al. (2006). Samples were hydrolysed with $2 \mathrm{M} \mathrm{KOH}$ in water:methanol $(1: 1)$ and the fatty acids extracted into petroleum spirit, methylated using $14 \% \mathrm{BF}_{3}$ in methanol and analysed by GLC. Samples were injected in the split mode, $70: 1$, onto a CP Sil $88,50 \mathrm{~m} \times 0.25 \mathrm{~mm}$ fatty acid methyl esters (FAME) column (Chrompack UK Ltd, London, UK) with helium as the carrier gas. The output from the flame ionization detector was quantified using a computing integrator (Spectra Physics 4270, Santa Clara, CA, USA) and linearity of the system was tested using saturated (FAME4) and monounsaturated (FAME5) methyl ester quantitative standards (Thames Restek UK Ltd, Windsor, Universal Biologicals (Cambridge) Ltd., Cambridge, UK), PUFA ( $n-3$; Matreya, Universal Biologicals (Cambridge) Ltd., Cambridge, UK), short to medium chain and branched chain fatty acids (bacterial acid methyl ester mix; Supelco, Sigma-Aldrich Company Ltd., Gillingham, UK) and a mix of C20 and C22 n-3 and $\mathrm{n}-6$ fatty acids made in the laboratory from a mix of methyl esters (Sigma, Sigma-Aldrich Company Ltd., Gillingham, UK). Total intramuscular fat concentration was calculated gravimetrically as total weight of fatty acid extracted.

\section{Sensory (eating) quality}

Sensory analysis was carried out by a 10-person trained taste panel (BSI, 1993). The samples were defrosted overnight at $4^{\circ} \mathrm{C}$ and then cut into steaks $20 \mathrm{~mm}$ thick. Steaks were grilled to an internal temperature of $74^{\circ} \mathrm{C}$ (measured by a thermocouple probe), turning over every $2 \mathrm{~min}$, after which all fat and connective tissue was trimmed and the muscle cut into $2 \mathrm{~cm}$ cubes. The blocks were wrapped in pre-labelled foils and placed in a heated incubator. The samples were then given to the assessors in a random order assigned by computer, according to MacFie et al. (1989). Panellists assessed samples from carcasses of two different chicorygrazed and two grass-grazed animals per session, four sessions in a morning using an eight-point category scale for tenderness, juiciness, beef flavour and abnormal flavour and $\mathrm{a} 0$ to $100 \mathrm{~mm}$ unstructured line scales where $0=$ nil and $100=$ extreme intensity for flavour descriptors chosen by the panel in previous training sessions.

\section{Statistical analysis}

All data were examined by ANOVA using GenStat ${ }^{\circledR}$ (Payne et al., 2014) and treating plots as experimental units and pasture type as a fixed effect. Colour saturation time courses were analysed by repeated measures ANOVA. Fatty acid composition as a percentage of the total fatty acid data were analysed by principal component analysis using Genstat ${ }^{\circledR}$. Taste panel intensity ratings (either on an eight-point category scale or 0 to 100 scale, values were standardised for panellists with the Fizz software and compared by ANOVA treating plots as experimental units with pasture type as a fixed effect.

\section{Results}

\section{Meat and fat measurements}

Muscle $\mathrm{pH}$ measured in the Longissimus muscle at 2 and $48 \mathrm{~h}$ after slaughter, fat colour, muscle vitamin $\mathrm{E}$ concentration and muscle fat oxidation stability (shown as TBARS) are presented in Table 1. These data showed there were no effects $(P>0.05)$ on meat quality of including chicory in the diet of grazing beef steers in the present study. As the display period in the modified atmosphere packs progressed, numerical difference in colour saturation decreased between the dietary treatment groups (Figure 1). However, in spite of numerically lower saturation values for samples from animals fed chicory at $24 \mathrm{~h}$ after packing in MA, and this difference persisting for 5 days postpackaging, there was no statistical evidence that diet influenced saturation or the rate of decline with time $(P>0.05)$.

Table 1 Effect of either chicory/ryegrass or ryegrass dietary treatments on the $\mathrm{pH}$, temperature and stability of the $\mathrm{M}$. Longissimus and carcass fat colour from beef steers grazing in a 2-year pasture-based finishing system

\begin{tabular}{lcclc}
\hline \hline & PRG & CH/PRG & SED & $P$-value \\
\hline pH & & & & \\
$\quad$ At 2 h & 6.18 & 6.26 & 0.100 & $\mathrm{Ns}$ \\
$\quad$ At $48 \mathrm{~h}$ & 5.59 & 5.71 & 0.054 & $\mathrm{Ns}$ \\
Temperature $\left({ }^{\circ} \mathrm{C}\right)$ & & & & \\
$\quad$ At 2 & 33.9 & 34.4 & 0.59 & $\mathrm{Ns}$ \\
$\quad$ At 48 & 2.56 & 2.43 & 0.369 & $\mathrm{Ns}$ \\
Fat colour & & & & \\
$\quad L^{*}$ (lightness) & 67.1 & 67.3 & 1.05 & $\mathrm{Ns}$ \\
$a^{*}$ (redness) & 3.24 & 3.83 & 0.935 & $\mathrm{Ns}$ \\
$\quad b^{*}$ (yellowness) & 17.2 & 20.7 & 2.99 & $\mathrm{Ns}$ \\
$\quad$ Chroma & 17.6 & 21.2 & 3.10 & $\mathrm{Ns}$ \\
$\quad$ Hue & 79.6 & 78.9 & 1.56 & $\mathrm{Ns}$ \\
Vitamin E (mg/kg) & 3.97 & 4.30 & 0.306 & $\mathrm{Ns}$ \\
Lipid oxidation (TBARS (mg/kg)) & 1.10 & 0.87 & $0.056^{1}$ & $\mathrm{Ns}$ \\
\hline \hline
\end{tabular}

PRG = perennial ryegrass; $C H / P R G=$ chicory $/$ perennial ryegrass; $S E D=$ standard error of the difference; Ns $=$ not significant $(P>0.05)$; TBARS $=$ thiobarbituric acid reacting substances.

${ }^{1}$ SED shown applies to means transformed to $\log _{10}$ scale. 


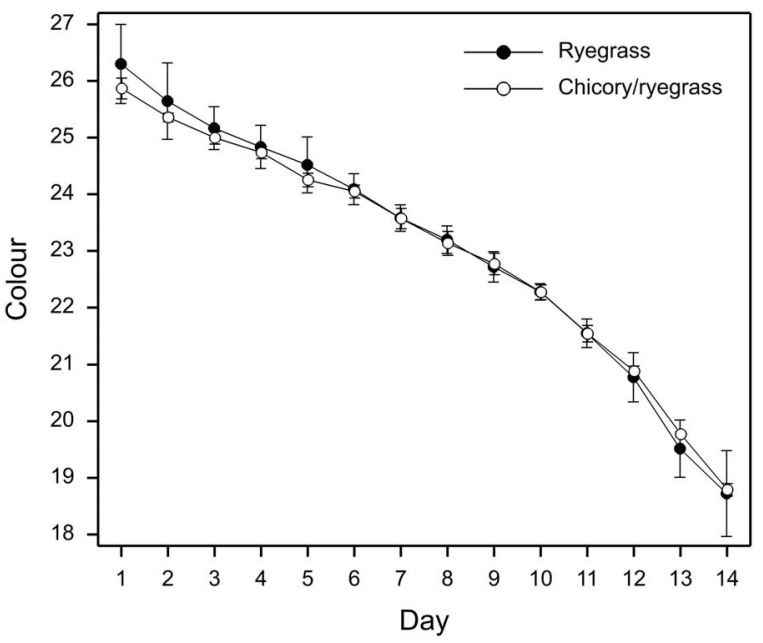

Figure 1 Effect of dietary treatment and time in simulated retail display in modified atmosphere packs on colour saturation $( \pm S E M)$ of $M$. Longissimus steaks from steers grazing either chicory/ryegrass or ryegrass-only swards in a 2-year pasture-based finishing system.

\section{Fatty acid composition and profile}

Data showed there were no differences in the levels of the total amount or relative proportion of selected individual fatty acids in the $M$. Longissimus steaks taken from beef steers grazing chicory/ryegrass or ryegrass-only swards within a 2-year pasture-based finishing system $(P>0.05)$ (Table 2). Figure 2 shows selected fatty acid compositions as a percentage of the total fatty acids did not differ between treatments $(P>0.05)$.

\section{Sensory (eating) quality}

Taste panel assessments found the sensory qualities of beef steaks from beef steers grazing chicory/ryegrass or ryegrassonly swards to be comparable with no difference in eating qualities, flavours or overall liking $(P>0.05)$ (Table 3$)$.

\section{Discussion}

The main findings of current study was that there were no substantive effects of including chicory in the swards of grazing beef cattle on meat stability, fatty acid composition or sensory properties when compared with beef steers grazing ryegrass-only swards. Many factors influence ruminant meat quality and these can be divided into two main categories: the animal factors (e.g. breed, age, gender) and environmental factors (e.g. diet, weather, slaughtering procedures) (Priolo et al., 2001). In many studies, the effect of diet on meat quality can be confounded by the effects of the diet on growth rates, making it difficult to determine if the meat characteristics are due to the effects of the diet or its effects on body composition per se (Muir et al., 1998). In the study reported here, previously published data confirmed that there were no differences in the growth rates, final live weight or carcass characteristics of the beef steers grazing either dietary treatment (Marley et al., 2014), allowing for a clear interpretation of the data without these factors confounding the investigation.
Table 2 Effect of either chicory/ryegrass or ryegrass dietary treatments on the selected fatty acid concentration (mg/100 g tissue), total fatty acid concentration (mg/100 g tissue) and fatty acid ratios of the M. Longissimus from beef steers grazing in a 2-year pasture-based finishing system

\begin{tabular}{|c|c|c|c|c|}
\hline & PRG & $\mathrm{CH} / \mathrm{PRG}$ & SED & $P$-value \\
\hline \multicolumn{5}{|c|}{ Fatty acids (mg/100 g tissue) } \\
\hline $14: 0$ & 64.6 & 59.9 & 8.31 & Ns \\
\hline $16: 0$ & 621 & 585 & 64.2 & Ns \\
\hline $16: 1 n-7$ & 102.2 & 96.8 & 12.12 & Ns \\
\hline $18: 0$ & 329.7 & 347.6 & 32.04 & Ns \\
\hline $18: 1 t 6-11^{1}$ & 49.4 & 49.7 & 10.17 & Ns \\
\hline $18: 1 n-9^{2}$ & 866 & 849 & 102.5 & Ns \\
\hline $18: 1 n-7$ & 29.4 & 29.3 & 2.69 & Ns \\
\hline $18: 2 n-6$ & 62.1 & 63.2 & 1.38 & Ns \\
\hline $18: 3 n-3$ & 39.0 & 38.9 & 0.91 & Ns \\
\hline $\mathrm{CLA}^{3} 9 \mathrm{C} 11 t$ & 10.8 & 10.1 & 2.34 & Ns \\
\hline $20: 3 n-6$ & 5.88 & 5.66 & 0.240 & Ns \\
\hline $20: 4 n-6$ & 20.9 & 20.7 & 0.94 & Ns \\
\hline $20: 4 n-3$ & 5.79 & 5.68 & 0.157 & Ns \\
\hline $20: 5 n-3$ & 17.13 & 17.39 & 0.716 & Ns \\
\hline $22: 4 n-6$ & 1.14 & 1.20 & 0.126 & Ns \\
\hline $22: 5 n-3$ & 21.8 & 22.1 & 0.33 & Ns \\
\hline $22: 6 n-3$ & 2.30 & 2.23 & 0.126 & Ns \\
\hline \multicolumn{5}{|c|}{ Total fatty acids (mg/100 g tissue) } \\
\hline Total & 2496 & 2455 & 249.3 & Ns \\
\hline Total SFA ${ }^{4}$ & 1017 & 994 & 100.8 & Ns \\
\hline Total MUFA ${ }^{5}$ & 1050 & 1028 & 126.0 & Ns \\
\hline Total PUFA ${ }^{6}$ & 176.1 & 177.1 & 2.45 & Ns \\
\hline Total $n-3^{7}$ & 86.0 & 86.3 & 1.20 & Ns \\
\hline Total $n-6^{8}$ & 90.0 & 90.8 & 1.66 & Ns \\
\hline \multicolumn{5}{|l|}{ Fatty acid ratios } \\
\hline PUFA:SFA & 0.2 & 0.2 & 0.02 & Ns \\
\hline$n-6: n-3$ & 1.05 & 1.05 & 0.018 & Ns \\
\hline
\end{tabular}

PRG = perennial ryegrass; $\quad$ CH/PRG = chicoryl perennial ryegrass; SED = standard error of the difference; $\mathrm{Ns}=$ not significant $(P>0.05) ; \mathrm{SFA}=$ saturated fatty acids; MUFA = monounsaturated fatty acids; PUFA = polyunsaturated fatty acids; CLA = conjugated linoleic acid.

${ }^{1}$ When using a 50-m CP-SIL 88 column, 18:1 trans- 6 to trans-11 are detected as a single peak, and $18: 1$ trans-12, $-13,-14,-15$ and -16 and $18: 1$ cis- 6 co-elute with 18:1 cis-9 (Molkentin and Precht, 1995). Therefore, measurements of 18:1 trans6 to trans-11 were used to estimate total trans $18: 1$ concentrations.

${ }^{2}$ Sum of trans-12 to trans-16 18:1 was used to correct cis-9 18:1 concentrations. ${ }^{3} 18: 2$ cis-9, trans- 11 (may also contain some trans-8, cis-10 CLA and trans-7, cis-9 CLA as minor isomers).

${ }^{4}$ SFA: sum of $12: 0,14: 0,16: 0,18: 0$.

${ }^{5}$ MUFA: sum of $16: 1,18: 1,18: 1 \mathrm{n}-9,18: 1 \mathrm{n}-7,20: 1 \mathrm{n}-9$.

${ }^{6}$ PUFA: sum of $18: 2 n-6,18: 3 n-3,20: 3 n-6,20: 4 n-6,20: 4 n-3,20: 5 n-3,22$ : $4 n-6,22: 5 n-3,22: 6 n-3$.

${ }^{7} n-3$, sum of $20: 4 n-3,20: 5 n-3,22: 5 n-3,22: 6 n-3$.

$8 n-6$, sum of $18: 2 n-6,20: 3 n-6,20: 4 n-6,22: 4 n-6$.

\section{Meat and fat measurements}

The colour saturation during retail simulation within the current study were not found to differ with both treatment being within the typical range reported for grazing systems (Priolo et al., 2001) and remaining above 18 until day 14 . A chroma value of 18 is considered the threshold value, which corresponds to the formation of $20 \%$ metmyoglobin (McDougall, 1982), the borderline value for consumer 


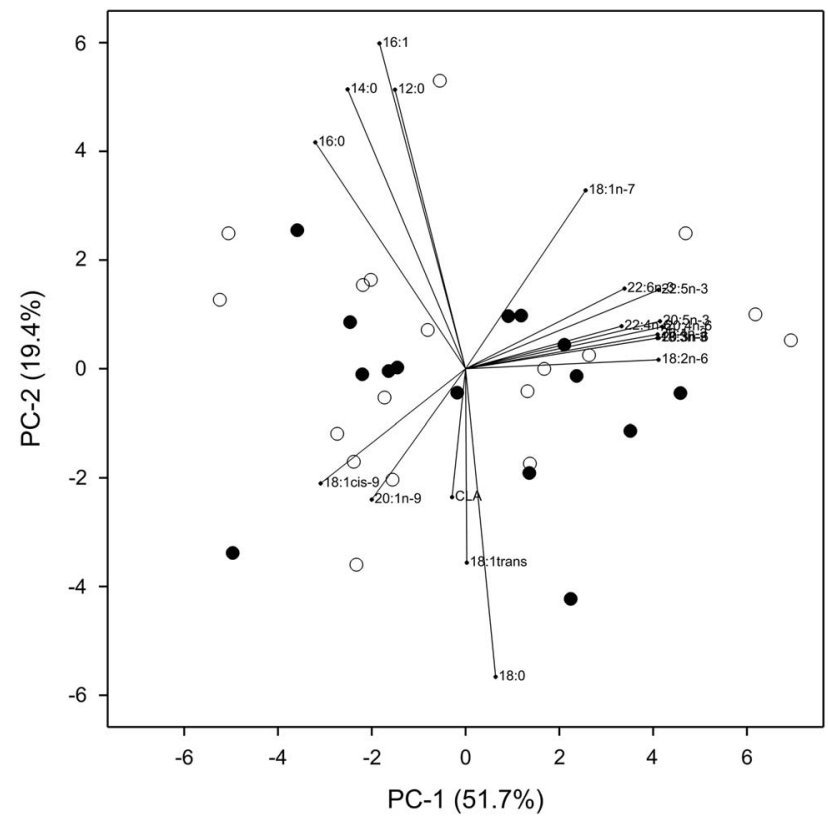

Figure 2 Principal component bi-plot showing the fatty acid compositions as a percentage of the total fatty acids of $M$. Longissimus steaks from steers grazing either chicory/ryegrass or ryegrass-only swards in a 2-year pasture-based finishing system.

rejection during the purchase of fresh beef (Hood and Riordan, 1973). Beef colour stability is known to differ among muscle type, with the $M$. Longissimus muscle being the most stable (O'Keeffe and Hood, 1982) and, therefore the findings reported here are only in reference to this muscle and may have differed if other muscle types were studied. In the current study, the muscle $\mathrm{pH}$ values, as shown by muscle $\mathrm{pH}$ values at $48 \mathrm{~h}$, show that the meat $\mathrm{pH}$ from both treatments in the current study was within the normal range (pH 5.5 to 5.8) for beef (Priolo et al., 2001), including studies on the $M$. Longissimus muscle from pasture-based systems (Warren et al., 2008a).

The concentration of vitamin $\mathrm{E}$ in meat affects muscle pigment in the longissimus muscle (myoglobin to brown metmyoglobin) and lipid oxidation (Realini et al., 2004). Studies have shown that chicory contains significantly higher concentrations of $\delta$-tocopherol (16.6 mg/kg dry matter (DM)) when compared with other forages (Larsen et al., 2012) but there were no differences in concentrations of the more bioactive forms of $\alpha$ - or $\beta$-tocopherol. Further research is needed to determine the effects of different tocopherol isomers in beef diets on meat quality. In the current study, the vitamin $E$ levels in the muscle of beef steers are similar when compared with those reported $(3.91 \mu \mathrm{g} / \mathrm{g}$ as $\alpha$-tocopherol) for the longissimus muscle of pasture fed beef by Realini et al. (2004) and higher than those reported for the longissimus muscle silage-fed beef (Warren et al., 2008a). Therefore, a lack of difference in the meat vitamin $E$ concentrations between the two treatments may also have contributed to the finding that there was no differences in the rate of change of colour chroma during the simulated retail display period. The TBARS values found in the current
Table 3 Effect of either chicory/ryegrass or ryegrass dietary treatments on the taste panel intensity ratings (either on an eight-point category scale or 1 to 100 scale, as stated) for beef steaks from steers grazing in a 2-year pasture-based finishing system.

\begin{tabular}{|c|c|c|c|c|}
\hline Attributes & PRG & $\mathrm{CH} / \mathrm{PRG}$ & SED & $P$-value \\
\hline \multicolumn{5}{|c|}{ 8-point category scale ${ }^{1}$} \\
\hline Texture & 4.5 & 4.6 & 0.15 & Ns \\
\hline Juiciness & 5.1 & 5.1 & 0.12 & Ns \\
\hline Beef flavour & 4.2 & 4.3 & 0.18 & Ns \\
\hline Abnormal flavour & 2.2 & 2.1 & 0.60 & Ns \\
\hline \multicolumn{5}{|l|}{ 100-mm line scale } \\
\hline Greasy & 9.2 & 8.5 & 1.73 & Ns \\
\hline Bloody & 12.8 & 12.6 & 2.72 & Ns \\
\hline Livery & 11.0 & 10.9 & 2.93 & Ns \\
\hline Metallic & 17.7 & 15.4 & 3.19 & Ns \\
\hline Bitter & 6.7 & 5.1 & 1.07 & Ns \\
\hline Sweet & 15.2 & 16.6 & 2.60 & Ns \\
\hline Rancid & 0.7 & 0.3 & 0.23 & Ns \\
\hline Fishy & 0.5 & 0.4 & 0.17 & Ns \\
\hline Acid & 7.3 & 5.7 & 1.07 & Ns \\
\hline Cardboard & 14.1 & 14.5 & 2.37 & Ns \\
\hline Vegetable/grass & 15.9 & 13.9 & 2.79 & Ns \\
\hline Dairy & 13.7 & 14.7 & 2.52 & Ns \\
\hline Overall liking ${ }^{2}$ & 48.6 & 50.7 & 2.10 & Ns \\
\hline
\end{tabular}

PRG = perennial ryegrass; $\quad \mathrm{CH} / \mathrm{PRG}=$ chicory/ perennial ryegrass; $\mathrm{SED}=$ standard error of the difference; Ns $=$ not significant $(P>0.05)$.

${ }^{1}$ Eight-point category scale used where 1 to $4=$ extremely, very, moderately, slightly lacking in the trait; 5 to $8=$ slightly, moderately, very and extremely present in the trait.

${ }^{2}$ Hedonic assessment.

study are within an acceptable range expected for the longissimus muscle of cattle grazing pastures, also likely due to elevated vitamin E concentrations (Warren et al., 2008a).

The inclusion or deficiency of certain minerals, which play a role in metalloproteins which act as antioxidants, such as copper (Huang et al., 2014) and cobalt (Kennedy et al., 1994) and selenium have been shown to alter meat quality either by reducing the rate of myoglobin or lipid oxidation of the longissimus muscle in beef (Realini et al., 2004), or lipid metabolism in tissues in sheep (Kennedy et al., 1994). Research has reported there are higher concentrations of copper and cobalt in chicory compared with ryegrass (Marley et al., 2013). However, data on the forage chemical composition (presented in Marley et al., 2014) showed no differences in ash concentration between the two forage treatments, which suggest the mineral composition may not have differed in the current study. However, the elevated vitamin $\mathrm{E}$ concentrations found in the meat in this study could have been responsible for the extended colour shelf life. Further studies are now needed to understand if there are any effects of the inclusion of chicory on the health value of the beef produced for human nutrition, such as higher levels of essential micro-nutrients or other vitamins.

Fatty acid composition and profile

It has been well defined in numerous studies that dietary fat concentration and fatty acid composition can alter 
meat quality (Wood et al., 2004; Scollan et al., 2014). Increasing the PUFA concentration in the diet of cattle typically increases the concentration of these fatty acids in beef (Scollan et al., 2001). In general, differences in the fatty acid ratios in meat are most apparent in studies comparing contrasting forage-based diets against concentrate-based diets (Warren et al., 2008b) and could be one explanation as to why there was no differences in the current study, particularly as the n-6:n-3 ratio was as low as 1.05 for the control, with below 3 being typical for beef (Scollan et al., 2006). That stated, fatty acid profiles have been shown to differ among forages, with chicory reported as having higher concentrations of C18: 3 when compared with grasses (including ryegrass), plantain, turnips, rape, triticale and borage (Clapham et al., 2005). In contrast to the current study, other research found that grazing beef steers on chicory increased the ratio of $n-6$ to $n-3$ fatty acids in the meat when compared with steers grazing bermudagrass, cowpea or lucerne but not those grazing pearl millet (Schmidt et al., 2013). Further research into the fatty acids profiles in chicory when grown and managed under different environmental conditions are now required to determine if feeding chicory to cattle could be used as an effective approach to improving beef fatty acid composition, with potentially beneficial consequences for human nutrition (Scollan et al., 2006).

\section{Sensory (eating) quality}

Further physiological mechanisms by which chicory could exhort an effect on the quality of meat from ruminant livestock may be due to its phytochemical composition. Chicory leaves contains a range of secondary plant compounds, including sesquiterpene lactones (bitter compounds), tannins and other phenolic compounds (Kisiel and Zielińska, 2001). These secondary metabolites have been shown scientifically to have effects on meat quality. Feeding diets with condensed tannins increases ultimate-pH in meat (Priolo et al., 2000). More notably, sesquiterpene lactones, found in chicory leaves (Kisiel and Zielińska, 2001), may reduce skatole (3-methyl indole), one of the compounds widely considered to cause boar taint in pork meat. In other research, degradation products of these sesquiterpene lactones, namely dihydrolactucin, tetrahydrolactucin and hydroxypenyacetic acid, were identified as the taint compounds in the milk of dairy cows on high chicory diets (Visser, 1992). These accounts led to anecdotal speculation that the same compounds could result in meat with a bitter taste. In the findings of the current study, there was no effect of including chicory in the diet of beef steers on eating quality. However, determining the concentrations of these secondary metabolites over the 2-year period of the current study, to confirm how these compare with other studies, was outside the constraints of the research so further research is needed to increase our understanding of the role of the secondary metabolites in chicory in meat quality.

Our findings are in contrast to the research comparing beef from steers grazing chicory to bermudagrass, cowpea, lucerne or pearl millet, where it was found that consumers preferred steaks from steers finished on all other treatments compared with chicory or bermudagrass (Schmidt et al., 2013). Although it is difficult to draw comparisons between cattle and sheep given species differences in grazing efficiencies and intakes of chicory (McCoy et al., 1997), research looking at pure chicory swards compared with ryegrass in finishing lamb systems found, in agreement with our study, that including chicory in the diet of grazing lambs did not have any substantive effects on meat eating quality (Houdijk et al., 2011).

In practical farm situations, chicory is typically used in one of two ways: either as a medium-term ley in a mix with grass and clovers or as a pure sward for a short-term lamb or deerfinishing crop, with most of the research showing higher productivity responses for sheep and deer being conducted using the specialist pure short-term forage chicory crops. However, due to the long-term nature of forage-based beef finishing systems, in the current study the chicory was sown within a mix with perennial ryegrass (sward contained 24\% and $14 \%$ chicory on a DM basis in Years 1 and 2, respectively; see Marley et al., 2014 for all forage data) to make the current experiment applicable to a practical farming system. Using chicory within a ryegrass mix was also more likely to reduce the risk of any potential effects of a wet grazing season on either DM intakes or sward damage whilst a 2-year experiment was completed. However, it is possible that this reduced the potential to detect any effects of chicory on meat quality that could result from offering a pure sward of chicory as the forage diet to grazing beef steers, either grazed each season or in the second season only, and further studies involving short-term grazing studies on pure swards of chicory are needed to investigate this.

Previous research into the effects of different forage species on meat quality, coupled with research showing that dietary fatty acid, antioxidant and secondary plant compounds can alter meat quality, provided some evidence that the inclusion of chicory in pasture swards might alter the meat colour stability, fatty acid and sensory properties of beef when used within pasture-based beef finishing systems. However, the overall findings from this current study showed that chicory can be offered to beef steers when used within ryegrass/chicory swards without any substantive effects on meat stability, fatty acid composition or sensory properties of the $M$. Longissimus muscle. Further studies into the effects of short-term pure chicory swards grazed either each season or in the second season only are now needed to further investigate the effects of using chicory in pasture-based beef finishing systems.

\section{Acknowledgements}

The authors would like to gratefully acknowledge the advice received on this work from Phil Evans (retired). The authors would like to gratefully acknowledge M. Leyland, N. Gordon, M. Scott, O. Martin, A. Baker, K.G. Hallett and H. Fleming for their help in sample collection and measurements. This work was sponsored by EBLEX (now AHDB Beef and Lamb), UK. Seed 
for the swards was donated by Germinal, UK. Institute of Biological, Environmental and Rural Sciences receives strategic funding from the Biotechnology and Biological Sciences Research Council.

\section{References}

British Standards Institution 1993. Assessors for sensory analysis. In: Guide to selection, training and monitoring of selected assessors (BSI 7667. BSI, London, UK. Cassens RG, Demeyer D, Eikelenboom G, Honikel KO, Johansson G, Nielson T, Rennerre M, Richardson RI and Sakata R 1995. Recommendation of a reference method for assessment of meat colour. Proceedings of the 41st Annual International Congress of Meat Science and Technology, 21 August 1995, San Antonio, TX, USA, C86, pp. 410-411.

Commission Internationale de l'Eclairage 1978. Recommendations on uniform colour spaces, colour difference equations, psychrometric colour terms, Supplement No. 2 to CIE publication No. 15 (E-1.3.1) 1971/ (TC-1.3.), Bureau de la Commission International de l'Eclairage, Paris, France.

Clapham WM, Foster JG, Neel JP and Fedders JM 2005. Fatty acid composition of traditional and novel forages. Journal of Agricultural and Food Chemistry 53, 10068-10073.

Hood DE and Riordan EB 1973. Discolouration in pre-packaged beef: Measurement by reflectance spectrophotometry and shopper discrimination. International Journal of Food Science \& Technology 8, 333-343.

Houdijk JGM, Baker A, Navajas EA, Richardson RI and Ross DW 2011. Finishing lambs on chicory increases killing out percentage and carcass conformation score without detrimental effects on sensory meat eating quality. Proceedings BSAS Annual Conference, 4-5 April, University of Nottingham, Nottingham, UK, p. 139.

Huang Y, Wang Y, Lin X and Guo C 2014. Effects of supplemental copper on the serum lipid profile, meat quality and carcass composition of goat kids. Journal Biological Trace Element Research 159, 140-146.

Kennedy DG, Kennedy S, Blanchflower WJ, Scott JM, Weir DG, Molloy AM and Young PB 1994. Cobalt-vitamin $B_{12}$ deficiency causes accumulation of odd-numbered, branched-chain fatty acids in the tissues of sheep. British Journal of Nutrition 71, 67-76.

Kisiel W and Zielińska K 2001. Guaianolides from Cichorium intybus and structure revision of Cichorium sesquiterpene lactones. Phytochemistry 57, 523-527.

Larsen MK, Fretté XC, Kristensen T, Eriksen J, Søegaard K and Nielsen JH 2012. Fatty acid, tocopherol and carotenoid content in herbage and milk affected by sward composition and season of grazing. Journal of Science of Food and Agriculture 92, 2891-2898.

Li G and Kemp PD 2005. Forage chicory (Cichorium intybus L.): a review of its agronomy and animal production. Advances in Agronomy 88, 187-222.

Liu Q, Scheller KK and Schaefer DM 1996. Technical note: a simplified procedure for vitamin E determination in beef muscle. Journal of Animal Science 74, 2406-2410.

MacFie HJ, Bratchell N, Greenhoff K and Vallis LV 1989. Designs to balance the effect of order of presentation and first-order carry-over effects in hall tests. Journal of Sensory Studies 4, 129-148.

Marley CL, Barrett J, Lampkin NH, Cook R and Keatinge R 2003. The effects of birdsfoot trefoil (Lotus corniculatus) and chicory (Cichorium intybus) on parasite intensities and performance of lambs naturally-infected with helminth parasites. Veterinary Parasitology 112, 147-155.

Marley CL, Fychan R, Davies JW, Scollan ND, Richardson RI, Theobald VJ, Genever E, Forbes AB and Sanderson R 2014. Effects of chicory/perennial ryegrass swards compared with perennial ryegrass swards on the performance and carcass quality of grazing beef steers. PLoS ONE 9, e86259. https://doi.org/ 10.1371/journal.pone.0086259.

Marley CL, Fychan R, Scott MB, Davies JW and Sanderson R 2013. Trace element content of chicory compared with perennial ryegrass, red clover or white clover over two harvest years. Proceedings of the 17th Symposium of European Grassland Federation, 23-26 June 2013, Akureyri, Iceland, pp. 252-253.
McCoy JE, Collins M and Dougherty CT 1997. Amount and quality of chicory herbage ingested by grazing cattle. Crop Science 37, 239-242.

McDougall DB 1982. Changes in the colour and opacity of meat. Food Chemistry 9, 74-88.

Meat and Livestock Commercial Service Ltd (MLCSL) 2016. Beef carcase authentication and verification services. Retrieved on 10 March 2016 from http://www.mlcsl.co.uk/publications/Beef-carcass-classification.pdf.

Molkentin J and Precht D 1995. Optimized analysis of trans-octadecenoic acids in edible fats. Chromatographia 41, 267-272.

Muir PD, Deaker JM and Bown MD 1998. Effects of forage- and grain-based feeding systems on beef quality: a review. New Zealand Journal Agricultural Research 41, 623-635.

O'Keeffe M and Hood DE 1982. Biochemical factors influencing metmyoglobin formation on beef from muscles of differing colour stability. Meat Science 7 , 209-228.

Payne RW, Murray DM, Harding S, Baird D and Soutar D 2014. Introduction to GenStat ${ }^{\circ}$ for WindowsTM, 17th edition. VSN International, Hemel Hempstead, UK. Priolo A, Micol D and Agabriel J 2001. Effects of grass feeding systems on ruminant meat colour and flavour. a review. Animal Research 50, 185-200.

Priolo A, Waghorn GC, Lanza M, Biondi L and Pennisi P 2000. Polyethylene glycol as a means for reducing the impact of condensed tannins in carob pulp: effects on lamb growth performance and meat quality. Journal of Animal Science 78, 810-816.

Realini CE, Duckett SK, Brito GW, Dalla Rizza M and De Mattos D 2004. Effect of pasture vs. concentrate feeding with or without antioxidants on carcass characteristics, fatty acid composition, and quality of Uruguayan beef. Meat Science $66,567-577$

Rumball W, Skipp RA, Keogh RG and Claydon RB 2003. 'Puna II' forage chicory (Cichorium intybus L.). New Zealand Journal of Experimental Agriculture 43, 53-55.

Schmidt JR, Miller MC, Andrae JG, Ellis SE and Duckett SK 2013. Effect of summer forage species grazed during finishing on animal performance, carcass quality, and meat quality. Journal of Animal Science 91, 4451-4461.

Scollan ND, Choi NJ, Kurt E, Fisher AV, Enser M and Wood JD 2001. Manipulating the fatty acid composition of muscle and adipose tissue in beef cattle. British Journal of Nutrition 85, 115-124.

Scollan ND, Dannenberger D, Nuernberg K, Richardson RI, MacKintosh S, Hocquette J-F and Maloney AP 2014. Enhancing the nutritional and health value of beef lipids and their relationship with meat quality. Meat Science 97, 384-394.

Scollan N, Hocquette JF, Nuernberg K, Dannenberger D, Richardson RI and Moloney A 2006. Innovations in beef production systems that enhance the nutritional and health value of beef lipids and their relationship with meat quality. Meat science 74, 17-33.

Tarladgis BG, Watts BM, Younathan MT and Dugan L Jr 1960. A distillation method for the quantitative determination of malonaldehyde in rancid foods. Journal of the American Oil Chemists Society 37, 44-48.

Teye GA, Sheard PR, Whittington FM, Nute GR, Stewart A and Wood JD 2006. Influence of dietary oils and protein level on pork quality. 1. Effects on muscle fatty acid composition, carcass, meat and eating quality. Meat Science 73, 157-165.

Visser FR 1992. Changes in milk flavour: effect of different feeds. In Milkfat flavour Forum (ed. New Zealand Dairy Research Institute), pp. 36-40. New Zealand Dairy Research Institute, Palmerston North, New Zealand.

Warren HE, Scollan ND, Enser M, Hughes SI, Richardson RI and Wood JD 2008b. Effects of breed and a concentrate or grass silage diet on beef quality in cattle of 3 ages. I: animal performance, carcass quality and muscle fatty acid composition. Meat Science 78, 256-269.

Warren HE, Scollan ND, Nute GR, Hughes SI, Wood JD and Richardson RI 2008a. Effects of breed and a concentrate or grass silage diet on beef quality in cattle of 3 ages. II: meat stability and flavour. Meat Science 78, 270-278.

Wood JD, Richardson RI, Nute GR, Fisher AV, Campo MM, Kasapidou E, Sheard PR and Enser M 2004. Effects of fatty acids on meat quality: a review. Meat Science 66, 21-32. 